\title{
Hormone responses to exogenous GnRH pulses in post-partum dairy cows
}

\author{
A. R. Peters*, M. G. Pimentel and G. E. Lamming \\ AFRC Research Group on Hormones and Farm Animal Reproduction, University of Nottingham, \\ School of Agriculture, Sutton Bonington, Loughborough, Leicestershire LE12 5RD, U.K.
}

\begin{abstract}
Summary. Nine Friesian dairy cows were treated with $2 \cdot 5 \mu \mathrm{g} \mathrm{GnRH}$ i.v. at 2-h intervals for $48 \mathrm{~h}$ commencing between Days 3 and 8 post partum. Hormone concentrations were measured in jugular venous plasma. An episodic pattern of LH release was induced in all animals and there was no significant change in amplitude during treatment. However, cows treated between Days 7 and 8 ('late') showed higher LH episode peaks than did those treated between Days 3 and 6 ('early'). Plasma FSH concentrations showed a less clear episodic pattern in response to GnRH injection. The mean height of FSH responses to GnRH tended to be higher in the 'early' group than in the 'late' group, as did mean FSH concentrations during the pretreatment sampling period. Although clear episodic changes were not observed, GnRH treatment induced a rapid sustained rise in plasma oestradiol-17 $\beta$ concentrations, indicating the responsiveness of ovarian follicles to gonadotrophin stimulation early in the post-partum period. There was no difference in oestradiol- $17 \beta$ concentrations between the 'early' and 'late' groups during the treatment period. Only one cow exhibited preovulatory-type LH, FSH and oestradiol-17 $\beta$ surges during the $96-\mathrm{h}$ post-treatment sampling period.

It is concluded that: (1) responsiveness to GnRH pulses increases significantly and FSH responsiveness tends to decrease with time post partum, (2) ovarian follicles are able to secrete oestradiol- $17 \beta$ in response to GnRH-induced $\mathrm{LH}$ and FSH release during the early post-partum period and there is no time-dependent change in responsiveness; and (3) the lack of preovulatory surges, except in one cow, may reflect a temporary defect in the positive-feedback mechanism by which high concentrations of oestradiol-17 $\beta$ induce preovulatory gonadotrophin release.
\end{abstract}

\section{Introduction}

Plasma LH concentrations are low during the early post-partum period in the dairy cow (Ingalls, Convey \& Hafs, 1973) but begin to rise between 5 and 10 days post partum coinciding with the onset of a pulsatile pattern of LH secretion and its subsequent increase in frequency (Carruthers \& Hafs, 1980; Peters, Lamming \& Fisher, 1981; Schallenberger, Oerterer \& Hutterer, 1982). Plasma FSH concentrations rise within 5 days after parturition with little subsequent change up to Day 30 (Lamming, Wathes \& Peters, 1981). Pituitary responsiveness, in terms of LH release, to single injections of $100-500 \mu \mathrm{g} \mathrm{GnRH}$ increases during the first 10 days post partum (Fernandes, Thatcher, Wilcox \& Call, 1978; Schallenberger, Schams \& Zottmeier, 1978; Foster, Lamming \& Peters, 1980) whilst responsiveness of the FSH gonadotrophs shows a tendency to decrease (Foster et al., 1980). However, these studies describe responses to pharmacological doses of $\mathrm{GnRH}$ and may not repre-

\footnotetext{
* Present address: Meat and Livestock Commission, P.O. Box 44, Queensway House, Bletchley, Milton Keynes MK2 2EF, U.K.
} 
sent physiologically relevant changes. Lower doses $(0 \cdot 5-5 \cdot 0 \mu \mathrm{g})$ of $\mathrm{GnRH}$ can induce LH pulses of physiological magnitude in the post-partum cow (Riley, Peters \& Lamming, 1981; Walters et al., 1982) but there is little information on time-dependent changes in response. Furthermore, a deficiency of those studies was a lack of close monitoring of the ovarian follicular responses to GnRH treatment. Therefore the present experiment was carried out to study changes in pituitary responsiveness during the early post-partum period to physiological levels of GnRH and to determine the short-term ovarian oestradiol response to $\mathrm{GnRH}$-induced gonadotrophin release.

\section{Materials and Methods}

Animals. Nine Friesian cows, calving between 24 October and 17 December, were milked twice daily and were fed a standard dairy ration according to milk yield. The cows were divided into two groups, 'early' and 'late', for which treatment was begun between Days 3 and $6(N=4)$ or between Days 7 and $8(\mathrm{~N}=5)$ post partum respectively.

Sampling procedures. Milk samples were taken three times weekly from parturition until the subsequent pregnancy was established. During the period of blood sampling milk samples were taken daily. Blood samples were taken via indwelling jugular venous catheters which were inserted at least $4 \mathrm{~h}$ before sampling began.

During blood sampling, different volumes of blood were taken, i.e. $2.5 \mathrm{ml}$ for LH and FSH assays alone, or $25 \mathrm{ml}$ to allow the additional assay of oestradiol- $17 \beta$. Blood samples $(2.5 \mathrm{ml})$ were taken at 15 -min intervals for an 8-h pretreatment period. During this period a 25 -ml sample was also taken at 2-h intervals. GnRH (Lutal: Hoechst AG, Frankfurt, FRG; $2.5 \mu \mathrm{g}$ in $4 \mathrm{ml} 0.9 \%$ (w/v) sterile $\mathrm{NaCl}$ ) was then injected intravenously at 2-h intervals for $48 \mathrm{~h}$. Samples $(25 \mathrm{ml})$ were taken at 15 -min intervals for the first $8 \mathrm{~h}$ of GnRH treatment. During the next $30 \mathrm{~h}$, paired blood samples were taken at 15 -min intervals every $2 \mathrm{~h}$, i.e. at 2 -h intervals a $25 \mathrm{ml}$ sample was taken, GnRH was injected and a second sample $(2.5 \mathrm{ml})$ was then taken $15 \mathrm{~min}$ later. During the last $10 \mathrm{~h}$ of $\mathrm{GnRH}$ treatment, $25-\mathrm{ml}$ samples were again collected at 15 -min intervals. Blood samples $(25 \mathrm{ml})$ were then taken at 4-h intervals for the next $96 \mathrm{~h}$.

Assay procedures. Progesterone in milk was assayed as described by Bulman \& Lamming (1978).

Plasma LH and FSH concentrations were measured as described by Webb, Lamming, Haynes, Hafs \& Manns (1977) and Webb, Lamming, Haynes \& Foxcroft (1980) respectively.

Plasma oestradiol-17 $\beta$ concentrations were assayed using duplicate 5-ml plasma samples by the method of Glencross \& Pope (1981) with the modified extraction procedure of Glencross, Abeywardene, Corney \& Morris (1981) as described by Peters (1984). The reliability criteria for the radioimmunoassays used are shown in Table 1.

Table 1. Reliability criteria for radioimmunoassay procedures

\begin{tabular}{|c|c|c|c|}
\hline \multirow[b]{2}{*}{ Assay } & \multirow{2}{*}{$\begin{array}{c}\text { Limit of } \\
\text { sensitivity* }\end{array}$} & \multicolumn{2}{|c|}{ Coefficients of variation $(\%) \dagger$} \\
\hline & & Intra-assay & Inter-assay \\
\hline Milk progesterone & $0.40 \mathrm{ng} / \mathrm{ml}$ & $7 \cdot 5$ & $10 \cdot 1$ \\
\hline Plasma LH & $0.40 \mathrm{ng} / \mathrm{ml}$ & $6 \cdot 5$ & $10 \cdot 3$ \\
\hline Plasma FSH & $10.5 \mathrm{ng} / \mathrm{ml}$ & $10 \cdot 9$ & $8 \cdot 0$ \\
\hline Plasma oestradiol-17 $\beta$ & $2.0 \mathrm{pg} / \mathrm{ml}$ & 17.9 & $22 \cdot 8$ \\
\hline
\end{tabular}


Analysis of data. An increase in LH concentrations was defined as an episode or pulse if there was an increase of at least $50 \%$ above the preceding value and this was followed by at least two points on the descending limb. Differences in hormone concentrations between groups of cows and between treatment periods were analysed by analysis of variance.

\section{Results}

\section{Pretreatment period}

Mean plasma hormone concentrations were calculated for the 8-h pretreatment period for each group of cows (see Table 2). Mean pretreatment plasma LH concentrations were significantly higher in the 'late' group than in the 'early' group $(P<0.01)$, but there was no significant difference in $\mathrm{LH}$ pulse frequency, FSH or oestradiol-17 $\beta$ concentrations.

\section{Treatment period}

Mean hormone concentrations for the two groups of cows during the first $8 \mathrm{~h}$ and last $10 \mathrm{~h}$ of the treatment period are shown in Text-fig. 1. Each GnRH injection resulted in a pulsatile $\mathbf{L H}$ response in the two groups although the pattern was less uniform in the 'early' group, particularly during the last $10 \mathrm{~h}$ of treatment. The mean $\mathrm{LH}$ concentration measured $15 \mathrm{~min}$ after each $\mathrm{GnRH}$ injection was significantly higher in the 'late' than in the 'early' group $(P<0.01$; see Table 2$)$. There was no significant change in the amplitude of the GnRH-induced LH response during the treatment period in either group although the $\mathrm{LH}$ response tended to be lower during the last $10 \mathrm{~h}$ of treatment compared to the first $8 \mathrm{~h}$ in the 'early' group (Text-fig. 1).

There was no significant difference in the mean FSH concentrations measured $15 \mathrm{~min}$ after GnRH injections between the two groups (see Table 2) although they tended to be lower in the 'late' group. The FSH responses to individual GnRH injections were irregular (see Text-fig. 1) with a tendency for two increases in FSH concentrations between each GnRH injection particularly in the 'late' group and the last $10 \mathrm{~h}$ of treatment in the 'early' group. The mean LH and FSH responses to all GnRH injections in the two groups of cows are shown in Text-fig. 2.

Plasma concentrations of oestradiol-17 $\beta$ increased in response to GnRH within 30 min of the first injections in both groups (see Text-fig. 1). However, concentrations fluctuated subsequently in a manner not directly related to the $\mathrm{GnRH}$ injections. There was no significant difference in the mean oestradiol-17 $\beta$ concentrations between the two groups. The 2-h mean oestradiol concentrations for all cows are shown in Text-fig. 3 and demonstrate an increase in plasma concentrations during the sampling period.

\section{Post-treatment period}

Sustained rises in plasma LH concentrations (mean values $>2.0 \mathrm{ng} / \mathrm{ml}$ ) occurred in 4 cows (B, $\mathrm{C}, \mathrm{E}$ and $\mathrm{H}$ ) during the post-treatment sampling period. However, only Cow $\mathrm{B}$ exhibited preovulatory-type surges of LH, FSH and oestradiol-17ß. In this cow the peak LH value $(24 \cdot 2 \mathrm{ng} / \mathrm{ml})$ was observed on Day 9 post partum and an increase in oestradiol-17 $\beta$ concentrations preceded the LH surge (see Text-fig. 4). Luteal function began on Day 15 as determined by milk progesterone concentrations.

\section{Milk progesterone concentrations}

There was no significant difference in the mean intervals to the first rise in milk progesterone concentrations greater than $3 \mathrm{ng} / \mathrm{ml}$ for the two groups (see Table 2). However, Cows A and I did not resume a normal cyclic pattern until Days 87 and 60 post partum respectively. 

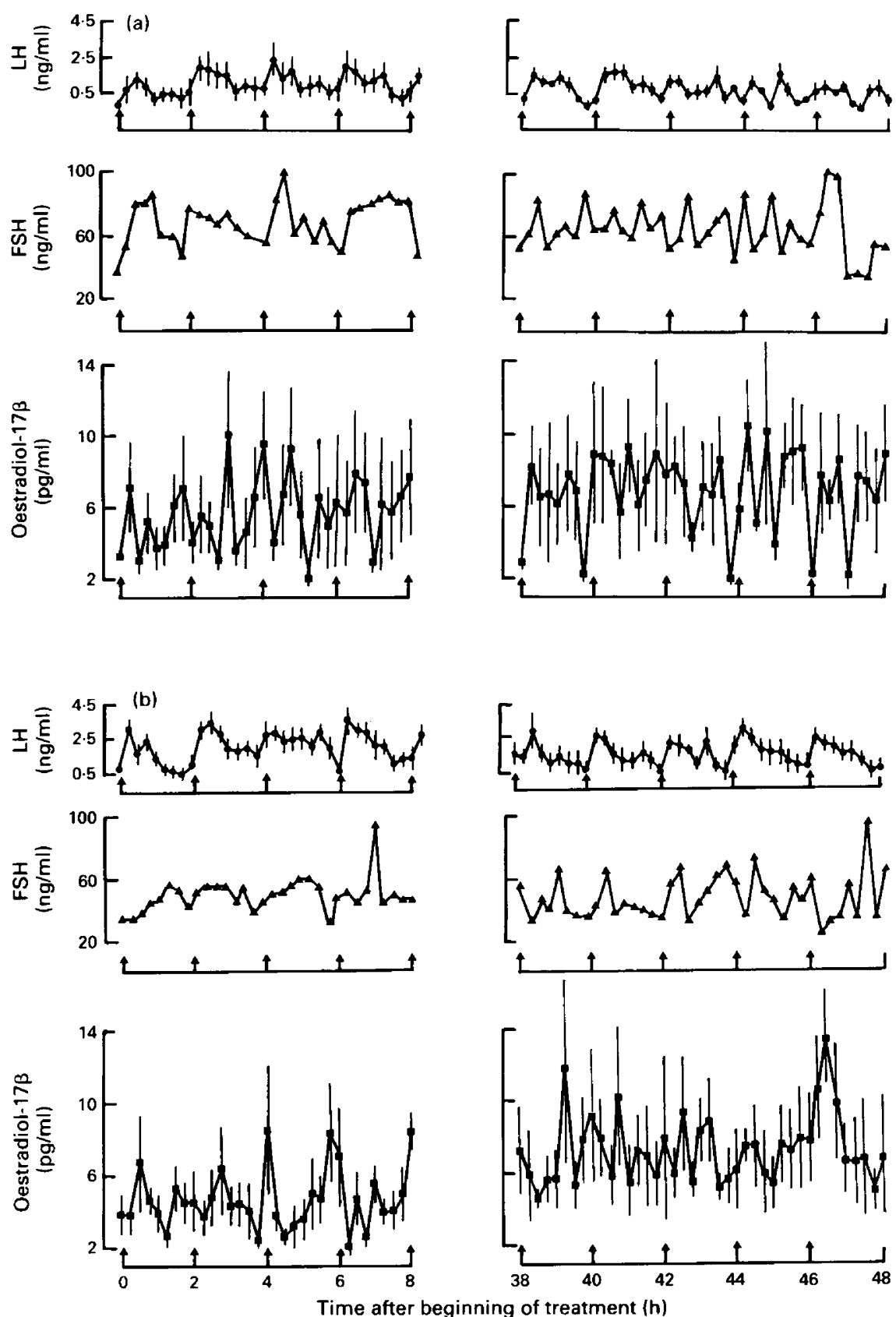

Text-fig. 1. Mean plasma concentrations of LH $(\bullet)$, FSH $(\Delta)$, and oestradiol-17 $\beta(\square)$ in response to 2-h injections of $2.5 \mu \mathrm{g} \mathrm{GnRH}$ (vertical arrows). Treatment wàs begun (a) between Days 3 and 6 post partum ('early' group) or (b) between Days 7 and 8 post partum ('late' group). Vertical bars represent s.e.m. The s.e.m. of the FSH concentrations ranged between 3.5 and $44.9 \mathrm{ng} / \mathrm{ml}$. 
Table 2. Characteristics of hormone secretion in cows before and after GnRH treatment

\begin{tabular}{|c|c|c|}
\hline & \multicolumn{2}{|c|}{ Groups } \\
\hline & $\begin{array}{c}\text { 'Early' } \\
\text { (Days 3-6; } N=4 \text { ) }\end{array}$ & $\begin{array}{c}\text { 'Late' } \\
\text { (Days 7-8; } N=5 \text { ) }\end{array}$ \\
\hline \multicolumn{3}{|l|}{ Before treatment } \\
\hline LH (ng/ml) & $0.98 \pm 0.03$ & $1 \cdot 81 \pm 0 \cdot 19$ \\
\hline $\mathrm{FSH}(\mathrm{ng} / \mathrm{ml})$ & $63 \cdot 80 \pm 4 \cdot 80$ & $46 \cdot 10 \pm 9 \cdot 20$ \\
\hline Oestradiol-17 $7 \mathrm{pg} / \mathrm{ml})$ & $3.27 \pm 0.48$ & $3.57 \pm 0.75$ \\
\hline \multicolumn{2}{|l|}{ LH pulse frequency } & $1 \cdot 80 \pm 0 \cdot 50$ \\
\hline \multicolumn{3}{|c|}{ At $15 \mathrm{~min}$ after each $\mathrm{GnRH}$ injection } \\
\hline LH (ng/ml) & $1.98 \pm 0.03$ & $3 \cdot 19 \pm 0 \cdot 17$ \\
\hline $\mathrm{FSH}(\mathrm{ng} / \mathrm{ml})$ & $65 \cdot 90 \pm 13 \cdot 20$ & $48 \cdot 0 \pm 12 \cdot 0$ \\
\hline \multicolumn{3}{|l|}{$\begin{array}{l}\text { Time to first rise in milk } \\
\text { progesterone conc. (days }\end{array}$} \\
\hline post partum) & $18 \cdot 25 \pm 5 \cdot 80$ & $26 \cdot 40 \pm 4 \cdot 55$ \\
\hline
\end{tabular}

Values are mean \pm s.e.m.

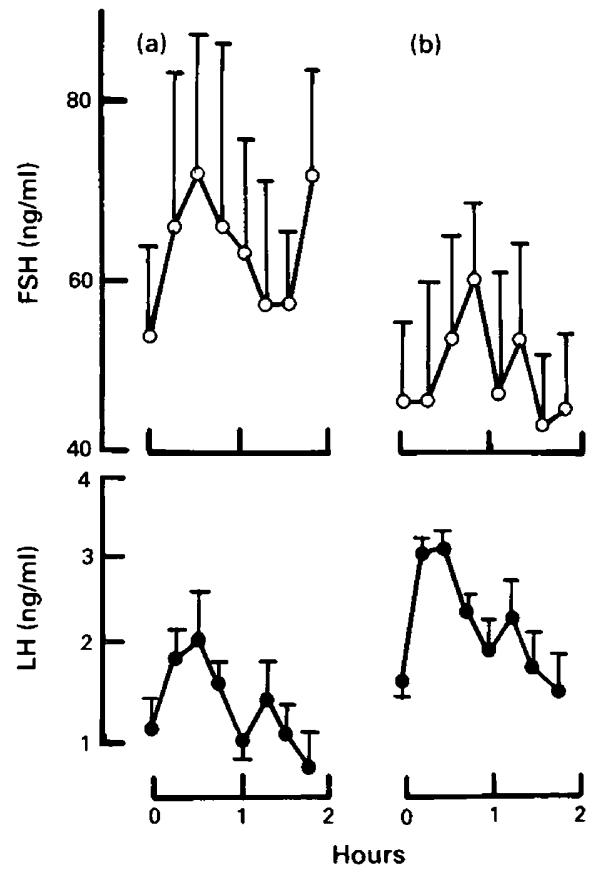

Text-fig. 2. Mean \pm s.e.m. plasma concentrations of FSH $(O)$ and $L H(O)$ after 2-h injections of $2.5 \mu \mathrm{g} \mathrm{GnRH}$ commencing (a) between Days 3 and 6 or (b) Days 7 and 8 post partum. 


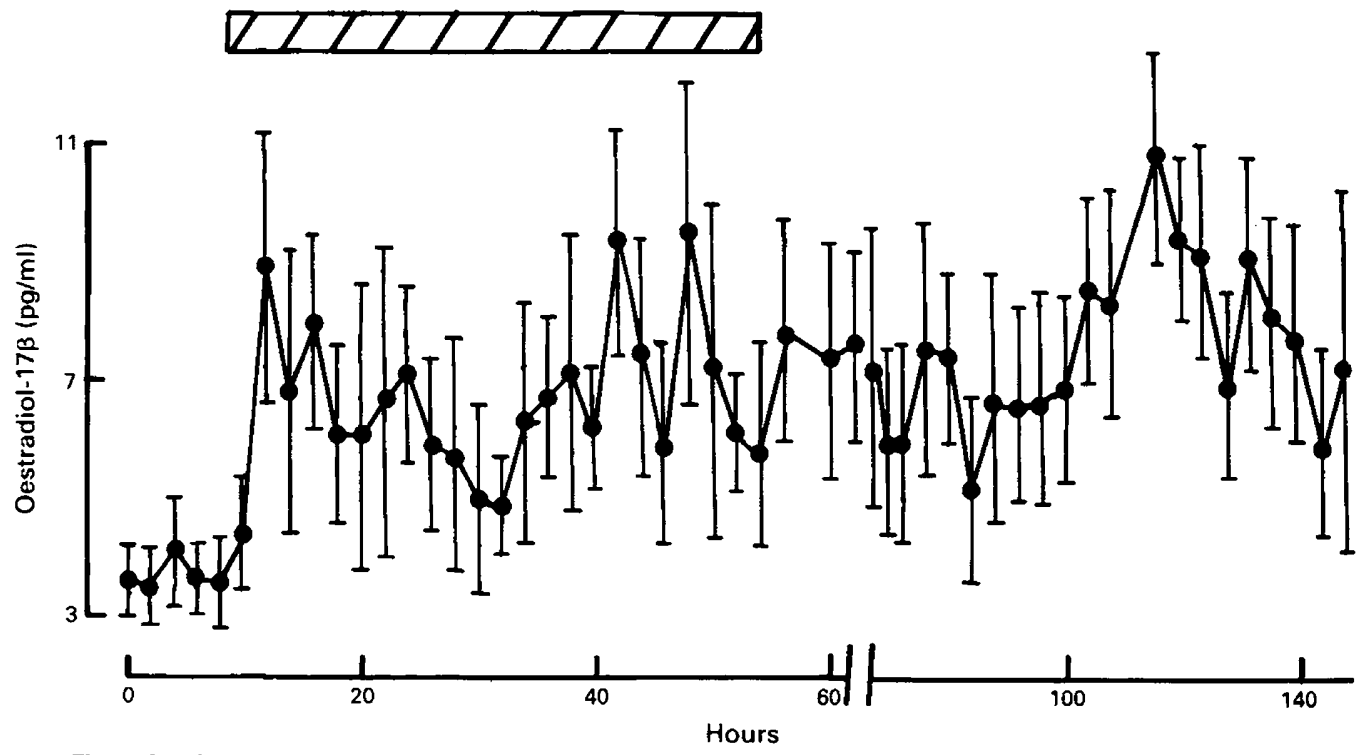

Text-fig. 3. Mean \pm s.e.m. plasma concentrations of oestradiol-17 $\beta$ in cows before during and after $24 \times 2.5 \mu \mathrm{g}$ GnRH injected at 2 -h intervals. The treatment period is denoted by the hatched area.

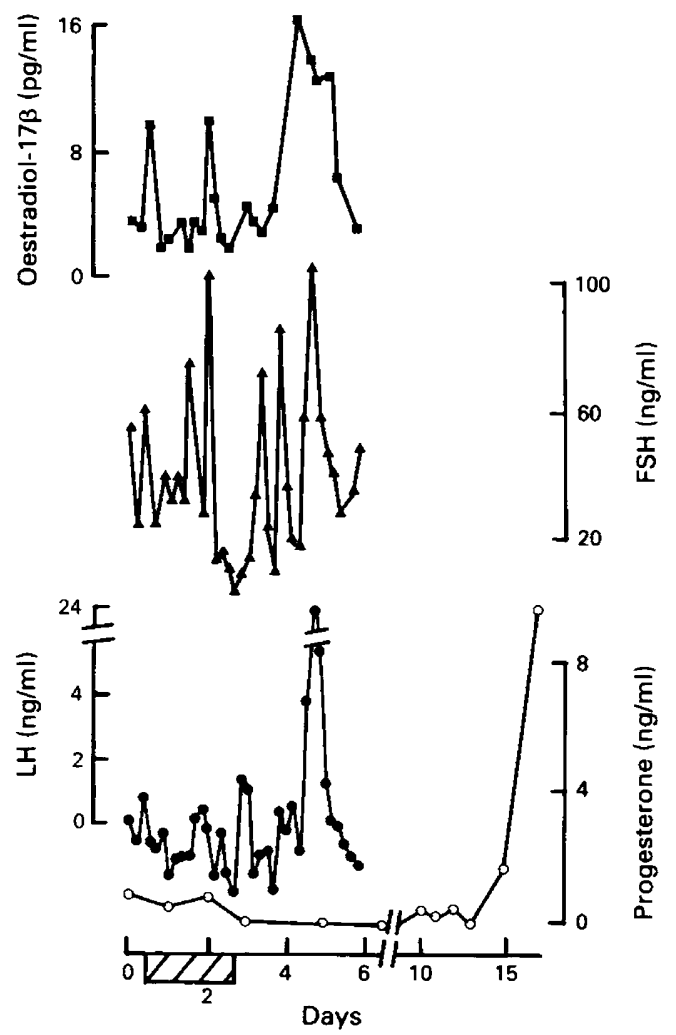

Text-fig. 4. Plasma concentrations of oestradiol-17 $\beta(\boldsymbol{D})$, FSH $(\Delta)$ and LH $(\Theta)$ and milk concentrations of progesterone $(O)$ in Cow B during the experimental period. The period of $\mathrm{GnRH}$ treatment is denoted by the hatched area. 


\section{Discussion}

During the pretreatment period, plasma LH concentrations were higher in the 'late' group than in the 'early' group of cows, a finding in agreement with previous results for dairy cows (Peters et al., 1981). Repeated injections of GnRH $(2.5 \mu \mathrm{g})$ induced an episodic pattern of LH release in all animals similar to that reported previously for beef cows (Riley et al., 1981; Walters et al., 1982). Although all cows in the present study showed GnRH-induced LH pulses, the pattern of response was more regular and of higher amplitude in the 'late' than in the 'early' group of cows. Foster et al. (1980) obtained a significantly greater $\mathrm{LH}$ response to a single injection of $200 \mu \mathrm{g} \mathrm{GnRH}$ administered on Day 7-10 post partum in dairy cows compared with cows injected on or before Day 5 post partum. It was on the basis of that study (Foster et al., 1980) that the cows in the present study were allocated to the 'early' and 'late' groups. There was no significant change in peak heights of induced LH episodes in any of the cows during the treatment period.

Plasma FSH concentrations during the pretreatment period were not significantly different between the two groups of cows, although concentrations in the 'late' group tended to be lower than those in the 'early' group. Plasma FSH concentrations have been shown to rise rapidly after parturition in the cow (Peters \& Lamming, 1984). It is possible that high plasma concentrations during the early post-partum period stimulate follicular growth and any subsequent decrease may be as a result of selective inhibition by the secretions of developing follicles.

Although the pattern varied between animals, FSH was released after each GnRH injection. Previous reports (Schams et al., 1978; Riley et al., 1981) have indicated that, in contrast to LH, FSH is not released in a pulsatile manner. However, Schallenberger et al. (1982) and Walters et al. (1982) have reported the presence of simultaneous LH and FSH pulses, and of additional FSH pulses between those of LH during the early post-partum period. In the present experiment an indistinct pulsatile release of FSH was observed. During the last $10 \mathrm{~h}$ of GnRH treatment in the 'early' group and throughout the treatment period in the 'late' group the pattern of FSH release was less regular than in the first $8 \mathrm{~h}$ of GnRH administration in the 'early' group (Text-fig. 1). One reason for this occasionally irregular pattern in LH and FSH concentrations could have been overlapping of natural and induced episodes.

Mean oestradiol-17 $\beta$ concentrations were low during the pretreatment period, consistent with other reports for the post-partum period (Hoffman et al., 1973; Rawlings, Weir, Todd, Manns \& Hyland, 1980). Staigmiller, England, Webb, Short \& Bellows (1982) reported a correlation between plasma oestradiol-17 $\beta$ concentrations and ovarian follicular size during the oestrous cycle. Therefore the similarity in the oestradiol- $17 \beta$ response to $\mathrm{GnRH}$ treatment in the two groups of cows in the present study might suggest that follicular growth is relatively uniform, at least between Days 3 and 8 post partum.

In the present and other studies in which blood samples have been taken from the jugular veins of cyclic (Walters, Schams \& Schallenberger, 1984) and post-partum (Rawlings et al., 1980) cows, episodes of oestradiol-17 $\beta$ could not be clearly detected. This is probably due to peripheral haemodilution of already-low concentrations of ovarian oestradiol-17 $\beta$. Oestradiol concentrations in samples collected from the caudal vena cava close to the junction with the ovarian vein are several-fold greater than those obtained by jugular vein blood sampling and an episodic pattern can be detected (Walters et al., 1984). A close relationship between episodes of LH and of oestradiol$17 \beta$ has been defined for the cyclic ewe (Baird, Swanston \& Scaramuzzi, 1976) and cow (Walters et al., 1984). Although in the present study there was no close relationship between episodes of LH and fluctuations in oestradiol concentrations, GnRH treatment induced a rapid sustained rise in plasma oestradiol concentrations, indicating the responsiveness of ovarian follicles to gonadotrophin stimulation early in the post-partum period.

Increases in basal LH concentrations during the $96-\mathrm{h}$ post-treatment blood sampling period occurred in 4 cows. These were similar to the pattern occurring before the first preovulatory LH surge post partum (Webb et al., 1980). This may suggest that preovulatory surges were imminent in 
these cows. However, only Cow B ('early' group) exhibited preovulatory hormone surges during the sampling period (Text-fig. 4). The preovulatory gonadotrophin surges occur as a result of a positive feedback action of high concentrations of oestradiol-17 $\beta$ acting on hypothalamus and pituitary (Kesner, Convey \& Anderson, 1981). In the present study increasing concentrations of LH were accompanied by elevated oestradiol- $17 \beta$ concentrations in 3 cows $(B, C$ and $\mathrm{H})$. However, Cow $E$ exhibited rising basal LH concentrations despite low levels of oestradiol-17 $\beta$ $(2 \cdot 0-4 \cdot 2 \mathrm{pg} / \mathrm{ml})$. Although no preovulatory surges occurred during the sampling period in Cows $\mathrm{C}$, $\mathrm{E}$ and $\mathbf{H}$, it is possible that they occurred soon afterwards because rises in milk progesterone concentrations were observed a short time later.

In conclusion, it is apparent that pituitary $\mathrm{LH}$ responsiveness to physiological-type stimulation by GnRH increases during the early post-partum period, whereas FSH responsiveness tends to decrease. The latter effect may be mediated by ovarian follicle secretions. The ovary is able to respond to GnRH-induced gonadotrophin release by secreting oestradiol-17 $\beta$ in the early postpartum period and there appears to be no time dependent change in responsiveness. Blood samples taken closer to the ovary, e.g. from the posterior vena cava (Walters et al., 1984), may help to define more clearly the pattern of oestradiol post partum. The fact that only one cow exhibited pre-ovulatory gonadotrophin surges in the face of high plasma oestradiol concentrations may suggest a temporary failure of the positive feedback mechanism. Other studies have indicated a time dependent recovery of this mechanism in beef and dairy cows (Schallenberger et al., 1982; Peters, 1984).

We thank Mrs S. Temple for technical assistance, Mr R. Temple and Mr A. Dingle for care of the animals, and the AFRC for financial assistance. M.G.P. was supported by a grant from the British Council.

\section{References}

Baird, D.T., Swanston, I. \& Scaramuzzi, R.J. (1976) Pulsatile release of $\mathrm{LH}$ and secretion of ovarian steroids in sheep during the luteal phase of the oestrous cycle. Endocrinology 98, 1490-1496.

Bulman, D.C. \& Lamming, G.E. (1978) Milk progesterone levels in relation to conception, repeat breeding and factors influencing acyclicity in dairy cows. J. Reprod. Fert. 54, 447-458.

Carruthers, T.D. \& Hafs, H.D. (1980) Suckling and four times daily milking; influence on ovulation, estrus and serum luteinising hormone, glucocorticoids and prolactin in post-partum holsteins. J. Anim. Sci. 50, 919-925.

Cekan, Z. (1975) Assessment of reliability of steroid radioimmunoassays. J. Steroid Biochem. 6, 271-275.

Fernandes, L.C., Thatcher, W.W., Wilcox, C.J. \& Call, E.P. (1978) LH release in response to GnRH during the post-partum period of dairy cows. J. Anim. Sci. 46, 443-448.

Foster, J.P., Lamming, G.E. \& Peters, A.R. (1980) Shortterm relationship between plasma $\mathrm{LH}, \mathrm{FSH}$ and progesterone concentrations in post-partum dairy cows and the effect of GnRH injection. J. Reprod. Fert. 59, $321-327$.

Glencross, R.G. \& Pope, G.S. (1981) Concentrations of oestradiol-17 $\beta$ and progesterone in the plasma of dairy heifers before and after cloprostenol-induced and natural luteolysis and during early pregnancy. Anim. Reprod. Sci. 4, 95-106.
Glencross, R.G., Abeywardene, S.A., Corney, S.J. \& Morris, H.S. (1981) The use of oestradiol-17 $\beta$ antiserum covalently coupled to sepharose to extract oestradiol-17ß from biological fluids. J. Chromatogr. biomed. Applic. 223, 193-197.

Hofiman, B., Schams, D., Gimenez, T., Ender, M.L., Herrmann, Ch. \& Karg, H. (1973) Changes of progesterone, total oestrogens, corticosteroids, prolactin and $\mathrm{LH}$ in bovine peripheral plasma around parturition with special reference to the effect of exogenous corticoids and a prolactin inhibitor respectively. Acta endocr., Copenh. 73, 389-395.

Ingalls, W.G., Convey, E.M. \& Hafs, H.D. (1973) Bovine serum $\mathbf{L H}, \mathbf{G H}$ and prolactin during late pregnancy, parturition and early lactation. Proc. Soc. exp. Biol. Med. 143, 161-164.

Kesner, J.S., Convey, E.M. \& Anderson, C.R. (1981) Evidence that estradiol induces the preovulatory $\mathbf{L H}$ surge in cattle by increasing pituitary sensitivity to LHRH and then increasing LHRH release. Endocrinology 108, 1386-1391.

Lamming, G.E., Wathes, D.C. \& Peters, A.R. (1981) Endocrine patterns of the post-partum cow. $J$. Reprod. Fert., Suppl. 30, 155-170.

Peters, A.R. (1984) Effects of exogenous oestradiol-17 $\beta$ on gonadotrophin secretion in post-partum beef cows. J. Reprod. Fert. 72, 473-478.

Peters, A.R. \& Lamming, G.E. (1984) Reproductive activity of the cow in the post-partum period. II. 
Endocrine patterns and induction of ovulation. $B r$. vet. J. 140, 269-280.

Peters, A.R., Lamming, G.E. \& Fisher, M.W. (1981) A comparison of plasma $\mathrm{LH}$ concentrations in milked and suckled post-partum cows. J. Reprod. Fert. 62, $567-573$.

Rawlings, N.C., Weir, L., Todd, B., Manns, J. \& Hyland, J.H. (1980) Some endocrine changes associated with the post partum period of suckling beef cows. $J$. Reprod. Fert. 60, 301-308.

Riley, G.M., Peters, A.R. \& Lamming, G.E. (1981) Induction of pulsatile $\mathrm{LH}$ release, FSH release and ovulation in post-partum acyclic beef cows by repeated small doses of GnRH. J. Reprod. Fert. 63, 559-565.

Schallenberger, E., Schams, D. \& Zottmeier, K. (1978) Response of gonadoliberin (GnRH) in pregnant and post-partum cattle including experiments with prolactin suppression. Theriogenology 10, 35-53.

Schallenberger, E., Oerterer, V. \& Hutterer, G. (1982) Neuroendocrine regulation of postpartum function. In Factors Influencing Fertility in the Post-Partum Cow, pp. 123-147. Eds H. Karg \& E. Schallenberger. Martinus Nijhoff, The Hague.

Schams, D., Schallenberger, E., Menzer, Ch., Stangl, J., Zottmeier, K., Hofiman, B. \& Karg, H. (1978) Profiles of $\mathrm{LH}, \mathrm{FSH}$ and progesterone in post-partum dairy cows and their relationships to the commencement of cyclic functions. Theriogenology 10, 453-462.
Staigmiller, R.B., England, B.G., Webb, R., Short, R.E. \& Bellows, R.A. (1982) Estrogen secretion and gonadotrophin binding by individual bovine follicles during estrus. J. Anim. Sci. 55, 1473-1482.

Walters, D.L., Short, R.E., Convey, E.M., Staigmiller, R.B., Dunn, T.G. \& Kaltenbach, C.C. (1982) Pituitary and ovarian function in postpartum beef cows. III. Induction of estrus, ovulation and luteal function with intermittent small-dose injections of GnRH. Biol. Reprod. 26, 655-662.

Walters, D., Schams, D. \& Schallenberger, E. (1984) Pulsatile secretion of gonadotrophins, ovarian steroids and ovarian oxytocin during the luteal phase of the oestrous cycle in the cow. J. Reprod. Fert. 71, 479-491.

Webb, R., Lamming, G.E., Haynes, N.B., Hafs, H.D. \& Manns, J.G. (1977) Response of cyclic and postpartum suckled cows to injections of synthetic LHRH. J. Reprod. Fert. 50, 203-210.

Webb, R., Lamming, G.E., Haynes, N.B. \& Foxcroft, G.R. (1980) Plasma progesterone and gonadotrophin concentrations and ovarian activity in post-partum dairy cows. J. Reprod. Fert. 59, 133-143.

Received 2 April 1985 